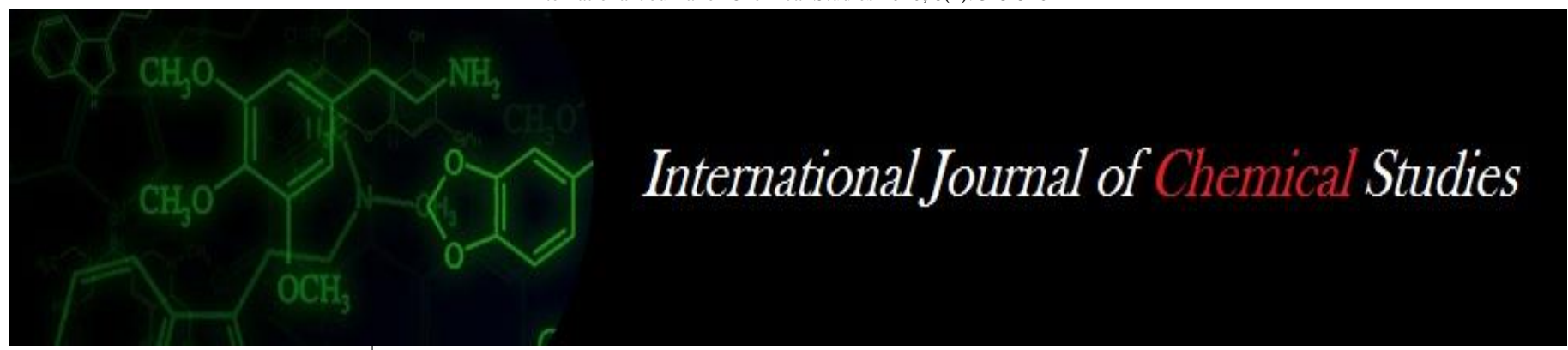

P-ISSN: 2349-8528

E-ISSN: 2321-4902

www.chemijournal.com

IJCS 2020; 8(2): 323-326

(C) 2020 IJCS

Received: 14-01-2020

Accepted: 18-02-2020

Dinesh Mani

Sheila Dhar Institute of Soil

Science, Department of

Chemistry, University of

Allahabad, Prayagraj, Uttar

Pradesh, India

\section{Adarsh Bhushan}

Sheila Dhar Institute of Soil

Science, Department of

Chemistry, University of

Allahabad, Prayagraj, Uttar

Pradesh, India

\section{Bechan Singh}

Sheila Dhar Institute of Soil

Science, Department of

Chemistry, University of

Allahabad, Prayagraj, Uttar

Pradesh, India

Vipin Sahu

Sheila Dhar Institute of Soil

Science, Department of

Chemistry, University of

Allahabad, Prayagraj, Uttar

Pradesh, India

Pravesh Kuma

Sheila Dhar Institute of Soil

Science, Department of

Chemistry, University of

Allahabad, Prayagraj, Uttar

Pradesh, India
Corresponding Author: Dinesh Mani

Sheila Dhar Institute of Soil

Science, Department of

Chemistry, University of

Allahabad, Prayagraj, Uttar

Pradesh, India

\section{Organic carbon status of sewage irrigated soils of Prayagraj Uttar Pradesh}

\author{
Dinesh Mani, Adarsh Bhushan, Bechan Singh, Vipin Sahu and Pravesh \\ Kumar
}

DOI: https://doi.org/10.22271/chemi.2020.v8.i2e.8787

\begin{abstract}
The representative soil samples were collected randomly from three sewage irrigated sites in Prayagraj, namely Beligaon, Kulbhaskar Ashram P.G. College and Baxibandh. Soil sampling was carried out by random sampling and representative soil samples were collected from different depths $(0-10 \mathrm{~cm}, 10$ $20 \mathrm{~cm}$ and $20-30 \mathrm{~cm})$. Average of soil organic carbon in the whole top layer $(0.643 \%)$ was more than the bottom layer $(0.60 \%)$ in different soil samples. The organic carbon content in each soil samples decreased with depth. Soil organic matter content in different sewage irrigated soils can be determined by using conversion factors with soil organic carbon content. The conversion factor is 1.724 , therefore, the level of soil organic matter is 1.724 multiplied by the soil organic carbon. The purpose of this research paper is to know how much and at which annual rate soil organic carbon can be accumulated in soils in different sewage irrigated sites of Prayagraj.
\end{abstract}

Keywords: Organic carbon, sewage irrigated, Prayagraj

\section{Introduction}

Soil organic carbon may be defined as carbon in soils derived from the decay of plant and animals' residues living and dead microorganisms and soil biota. Soil organic matter and soil organic carbon constitute usually a small portion of soil but they are one of the most important components of soil (Jorn et al., 2014) ${ }^{[6]}$. A soil organic carbon assessment of different sewage irrigated soil involves various steps: sampling, strategy, timing and design soil collection tools, depths and techniques; handling, storage, labeling and aggregation of samples; laboratory analyses; and verification techniques. Methodological differences in each step can lead to different estimated soil organic carbon values for the same location of these three specific sewages irrigated site of Prayagraj. Soil organic matter persistence is rather affected by soil organic carbon stabilization in the soil matrix through its interaction and association with soil minerals (Schmidt et al., 2015). Besides the decrease in the use of freshwater wastewater reuse also may reduce the discharge of effluents into freshwater ecosystems, enriching the soil with organic matter, macro and micro nutrients (Ganjegunte et al., 2018) ${ }^{[5]}$. The soil organic matter content is considered one of the most important soil properties affected by sewage water irrigation, as has been described by many studies reporting an increase of organic matter content in irrigated soils (Sanchez-Gonazalez et al., 2017) ${ }^{[1]}$. Sewage irrigation water can increase the risk of crop and ground water pollution and reduce soil quality and the infiltration rate (Yadav et al., 2015) ${ }^{[12]}$. Soil organic matter content can be positively or negatively affected by sewage water irrigation because it can improve soil fertility or cause its contamination by heavy metals accumulation at the same time (Bernier et al., 2013) ${ }^{[2]}$.

However, besides high concentration of organic matter in sewage wastewater typically contains large amount of pollutants including detergents, heavy metals, pharmaceuticals including antibiotics as well as pathogenic and antibiotic resistant bacteria carrying resistance determinants and mobile genetic elements (Manzetti et al., 2014) ${ }^{[7]}$. The physical and monetary constraints of collecting data, most methodologies quantify soil organic carbon stock to specific depths typically $0.3 \mathrm{~m}$ or $1 \mathrm{~m}$ extrapolate vertically from near surface measurements (Yang, et al., 2016) ${ }^{[13]}$. Soil organic carbon is the epicenter of soil physical, chemical and biological health (Chen et al., 2017) ${ }^{[3]}$. Loss of organic matter could cause soil aggregates to break down easily and accordingly become more erodible. 
Parallel to the increase in soil organic matter soil porosity increased, while bulk density and soil erodibility decreased (Rucknagel et al., 2016 and Zhong et al., 2017) ${ }^{[9,14] .}$

\section{Materials and Methods \\ Experimental site}

After a systematic survey the representative soil samples were collected randomly from three major areas in Prayagraj, namely Beligaon, Kulbhaskar and Baxibandh sewage irrigated sites. The experimental sites are situated in Northern India at $25^{\circ} 20^{\prime}$ to $25057^{\prime} \mathrm{N}$ latitude and $81^{\circ} 52^{\prime}$ to $81^{0} 56^{\prime} \mathrm{E}$ longitude on south-east facing slopes of comparable inclination at altitudes between $200 \mathrm{~m}$ and $80 \mathrm{~m}$ above sea level. SDI Farm is situated on the confluence of rivers Ganga and Yamuna at Prayagraj which belongs to the India tropical sub-humid region of Indo-Gangetic plain. The mean annual maximum and minimum temperature ranged between $22^{\circ} \mathrm{C}$ and $9^{\circ} \mathrm{C}$ respectively. The mean relative humidity is about $59 \%$ which rises to $81 \%$ during wet season and goes down to $29 \%$ during dry season.

\section{Soil analysis}

\section{Soil sampling}

All the three sewage irrigated sites namely Beligaon, Kulbhaskar and Baxibandh, receiving sewage irrigation for more than 25 years, depth-wise $(0-10 \mathrm{~cm}, 10-20 \mathrm{~cm}$ and $20-$ $30 \mathrm{~cm})$ soil samples were collected from randomly selected these three specific sewage irrigated sites. This was to ensure that soil samples are well distributed over the study and are representative of the organic carbon content of that specific sites or area (Ololade et al., 2010) ${ }^{[8]}$. The intention was to take a sample that is descriptive of the layer being sampled. The soil auger was driven from $0 \mathrm{~cm}$ to $30 \mathrm{~cm}$ into the top soil for the top layer and bottom layer respectively (Chiti et al., 2010) ${ }^{[4]}$.

\section{Soil pH}

Soil $\mathrm{pH}$ was measured with 1:2.5 soil water ratio using ELICO pH meter (Model LI 127) at the laboratory of Sheila
Dhar institute of soil science, University of Allahabad, Prayagraj -211002, U.P., India. Double distilled water used for the preparation of all solutions.

\section{Organic carbon}

Samples were air dried, ground with wooden pestle and mortar and pass through $0.2 \mathrm{~mm}$ size sieve to determine the soil organic carbon content as procedure outlined by Walkey and Black (1934) ${ }^{[11]}$.

$2 \mathrm{~g}$ of soil $(0.5 \mathrm{~mm})$ was taken in a $500 \mathrm{ml}$ conical flask, then $10 \mathrm{ml}$ of $1 \mathrm{~N}$ potassium dichromate $\left(\mathrm{K}_{2} \mathrm{Cr}_{2} \mathrm{O}_{7}\right)$ solution and 20 $\mathrm{ml}$ of concentrated sulphuric acid $\left(\mathrm{H}_{2} \mathrm{SO}_{4}\right)$ were added. The solution was shaken well for 2 minutes kept for half an hour and then diluted with $20 \mathrm{ml}$ of orthophosphoric acid and $1 \mathrm{ml}$ of diphenylamine indicator were added in solution. The solution becomes deep violet in colour and further it was titrated against N/2 ferrous ammonium sulphate solution, till the violet colour changed to purple and finally to green colour. A blank titration in a similar manner without the soil is carried out.

\section{Statistical analysis}

The experimental results were expressed as mean \pm standard error of mean of three replicates. Graphpad Prism (Version 5.04, Graphpad Software, USA) software was used for drawing figures.

\section{Result and discussion}

The three profiles of Beligaon, Kulbhaskar Ashram P.G. College and Baxibandh were characterized by a high $\mathrm{pH}$ of $7.6 \pm 0.2$ content with a general increase with depth. The sewage irrigated soils of Baxibandh site $(0.65 \%)$ are characterized by the highest organic carbon content among the three sewage irrigated soils, while the sewage irrigated soils of Kulbhaskar Ashram P.G. College site by the lowest one $(0.60 \%)$. The content of organic carbon in these three sewage irrigated sites is usually uniform, independently of the organic matter content in sewage irrigated sites.

Table 1: Organic carbon content in different sewage-irrigated sites of Prayagraj

\begin{tabular}{|c|c|c|c|c|c|}
\hline \multirow{2}{*}{ Depth (cm.) } & \multirow{2}{*}{ Non-sewage soils } & \multicolumn{3}{|c|}{ Sewage irrigated soils } \\
\cline { 3 - 5 } & & Beligaon & Kulbhashkar & Buxibandh & Mean \\
\hline $0-10$ & 0.49 & 0.66 & 0.65 & 0.67 & 0.66 \\
\hline $10-20$ & 0.43 & 0.65 & 0.60 & 0.65 \\
\hline $20-30$ & 0.36 & 0.61 & 0.55 & 0.62 \\
\hline Mean & 0.42 & 0.64 & 0.60 & 0.59 \\
\hline
\end{tabular}

Organic Matter (\%) of different sewage irrigated sites

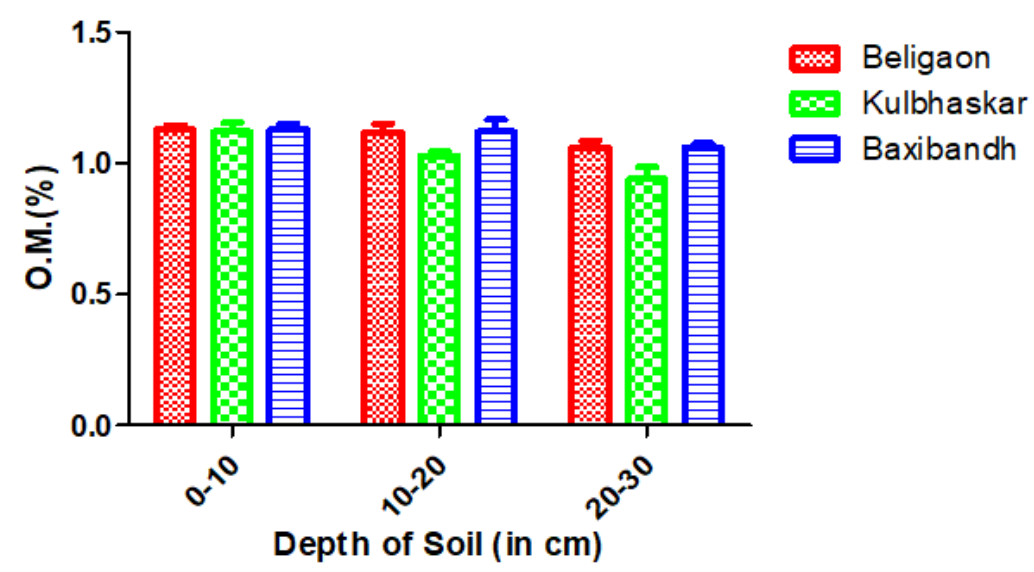

Fig 1: Organic carbon (\%) in different sewage irrigated soils of Prayagraj 


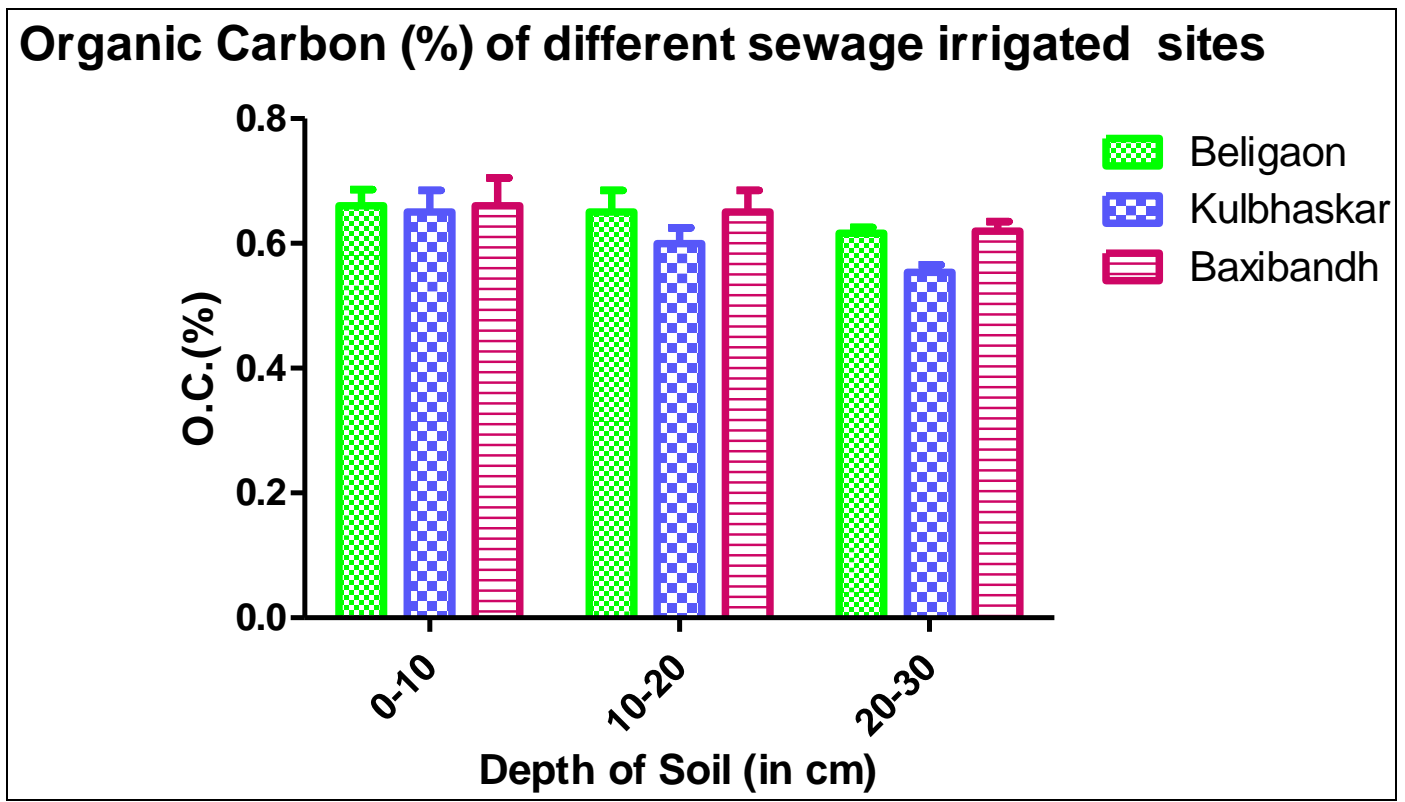

Fig 2: Organic matter (\%) in different sewage irrigated soils of Prayagraj

Table 2: Organic matter (\%) in sewage irrigated soils and non-sewage irrigated soil

\begin{tabular}{|c|c|c|c|c|c|}
\hline \multirow{2}{*}{ Depth (cm) } & \multirow{2}{*}{ Non-sewage irrigated soil } & \multicolumn{4}{|c|}{ Sewage irrigated soils } \\
\cline { 3 - 6 } & & Beligaon & Kulbhaskar & Baxi bandh & Mean \\
\hline $0-10$ & 0.85 & 1.13 & 1.12 & 1.14 & 1.13 \\
\hline $10-20$ & 0.74 & 1.12 & 1.03 & 1.13 & 1.09 \\
\hline $20-30$ & 0.62 & 1.06 & 0.94 & 1.06 & 1.02 \\
\hline Mean & 0.72 & 1.10 & 1.03 & 1.11 & \\
\hline
\end{tabular}

Organic matter being the food of microorganisms provides the substrate for growth and activities of microorganisms. Increase in bacterial population with application of sewage sludge was also reported by Singh et al. (2014). Organic matter is more difficult to measure accurately than organic carbon. As a result, the conversion factor of 1.724 is too low for most soils.

\section{Relation between SOM and SOC}

$55-58 \%$ soil organic carbon is found in soil organic matter. Soil organic carbon was highly correlated with SOM and it could be estimated by the conversion factor. The conversion factor is 1.724 therefore; the level of soil organic matter is 1.724 multiplies by the soil organic carbon. The relationship between soil organic carbon and soil organic matter was positively correlated which means that soil organic carbon or soil organic matter increases with increasing concentration of soil organic matter and soil organic carbon. This has been suggested that soil organic carbon and soil organic matter ratio varies depending on soil types and depth.

\section{Conclusion}

The overall mean content of organic carbon in sewage irrigated soils of Prayagraj was higher over their respective content in normal soil of Prayagraj. The content of organic carbon was significantly higher in all sewage irrigated soils at all the three depths $(0-10 \mathrm{~cm}, 10-20 \mathrm{~cm}$ and $20-30 \mathrm{~cm})$. The maximum accumulation of organic carbon in soil of sewage irrigated sites of Prayagraj is due to continuous use of sewage water. Sewage irrigation has a strong influence on the physical, chemical and biological properties of soil. The aim of this study is to investigate variations in soil organic carbon in the horizons of different sewage irrigated soils of Prayagraj. The sorption/complexation by soil organic matter, clay minerals and oxides is an important phenomenon for heavy metal retention and movement in soils. Long-term use of sewage water for irrigation increased the amount of organic carbon in soil and improved the soil fertility. However, a strict monitoring of metal accumulations in soil has to be undertaken at periodical interval. Heavy metals react with organic matter, clay exchange sites, carbonate and oxide surfaces and precipitate as hydroxide, carbonates, sulphides, phosphates and silicates in soil. Metal immobilisation through precipitation and adsorption is also considered a common mechanism to decrease the hazards of contaminated soils. However, further study is required to unreveal the processes of complexation of heavy metals with organic matter.

\section{References}

1. Sanchez-Gonazalez A, Chapela-Lara M, GermanVenegas E, Fuentes-Garcia R, Del Rio-Portilla F, Siebe C. Changes in quality and quantity of soil organic matter stocks resulting from wastewater irrigation in formerly forested land. Geoderma. 2017; 306:99-107.

2. Bernier MH, Levy GJ, Fine P, Borisover M. Organic matter composition in soils irrigated with treated wastewater. FT-IR Spectroscopic analysis of bulk soil samples. Geoderma. 2013; 209(210):233-240.

3. Chen Z, Wang H, Liu X, Zhao X, Lu D, Zhou J et al. Changes in soil microbial community and organic carbon fraction under short term straw return in a rice-wheat cropping system. Soil and Tillage Research. 2017; 165:121-127.

4. Chiti T, Certini G, Grieco E, Valentini R. The role of soil in storing carbon in tropical rainforests: the case of Ankas Park, Ghana. Plant and Soil. 2010; 33(1):453-461.

5. Ganjegunte G, Ulery A, Niu G, Wu Y. Organic Carbon, nutrient, and salts salt dynamics in saline soil and switch grass (Panicum virgatum L.) irrigated with treated 
municipal wastewater Land Degrad. Dev. 2018; 29(1):80-90.

6. Jorn PW, Scharlemann EVT, Heiderer R, Kapos V. Global soil carbon: Understanding and managing the largest terrestrial carbon pool. Carbon Manage. 2014; 5:81-91.

7. Manzetti S, Ghisi R. The environmental release and fate of antibiotics, Mar. pollut. Bul. 2014; 179:7-15.

8. Ololade IA, Ajayi IR, Gbadamosi AE, Mohammed OZ, Sunday AG. A study on Effects of soil physico-chemical Properties on Cocoa production in Ondo state. Modern Applied Science, 2010; 4(5).

9. Rucknagel J, Gotze P, Koblenz B, Bachmann N, Lobner $\mathrm{S}$, Linder $\mathrm{S}$ et al. Impact on soil physical properties of using large grain legumes for catch crop cultivation under different tillage condition. European Journal of Agronomy. 2016; 77:28-37.

10. Schmidt MWI, Tom MS, Abiven S, Dittmar T, Guggenberger G, Jonssens IA et al, Persistence of soil organic matter as an ecosystem property, Nature. 2011; 478:49-50.

11. Walkey A, Black AI. An examination of the Degtjarett method for determining soil organic matter and a proposed modification of chromic acid titration method. Soil Sci. 1934; 37:29-38.

12. Yadav RK, Minhas PS, Lal K, Chaturvedi RK, Yadav G, Verma TP. Accumulation of metals in soils, Groundwater and Edible Parts of Crops Grown under Long Term Irrigation with Sewage Mixed Industrial Effluents. Bull. Environ. Contam. Toxicol, 2015.

13. Yang R. et al. Precise estimation of soil organic carbon stocks in the northest Tibetan Plateau. Scientific Reports. 2016; 6:21842.

14. Zhong X, Li J, Li X, Ye S. Liu P. Hallett $\mathrm{M}$ et al. Physical protection by soil aggregates stabilizes soil organic carbon under simulated $\mathrm{N}$ deposition in a subtropical Forest of China. Geoderma. 2017; 285:323332. 